\title{
KONVERSI LAHAN DAN STRUKTUR PRODUKSI KEBUN: STUDI KASUS TERBENTUKNYA PERKEBUNAN KELAPA SAWIT RAKYAT PADA DUA DESA SAWAH ETNIS SERAWAI DAN JAWA DI KABUPATEN SELUMA, PROPINSI BENGKULU
}

\author{
Septri Widiono \\ Jurusan Sosial Ekonomi Pertanian Fakultas Pertanian Universitas Bengkulu
}

\begin{abstract}
Estate small landholders of palm oil were developed by converting wetland area. This research was aimed to study conversion of wetland area into palm oil estate, to study palm oil estate profile of farmers, and to formulate the structure of estate production. This research used survey method combining with indepth interviews. Sixty respondents were selected using simple random sampling method and data were analysed using an analytical description. The finding of this research showed that land conversion occurs due to decreasing village economic under wetland agricultural system. Palm oil estate farmers profile differs between two villages, namely Pasar Seluma (Serawai ethnic) and Rawasari (Java ethnic) in terms of land ownership, productivity, and labour relation. Finally, the production structure were also significantly difference with wetland agricultural system in which the estate agricltural system close to the structure of oil palm industry.
\end{abstract}

Key word: land conversion, palm oil estate, structure of production

\section{PENDAHULUAN}

Penurunan luas sawah terjadi di berbagai tempat di Indonesia akibat konversi sawah menjadi areal non pertanian. Apabila di sentra-sentra produksi padi di pulau Jawa, konversi sawah didominasi oleh peralihan menjadi permukiman, industri manufaktur, dan fasilitas perkotaan (Kustiwan 1997, Ashari 2003), maka di Bengkulu ada indikasi penurunan luasan lahan produksi padi umumnya menjadi lahan pertanian bukan sawah. Menurut Sensus Pertanian 2003, 148.697,5 ha lahan sawah yang mengalami konversi menjadi lahan pertanian bukan sawah selama tiga tahun terakhir di Propinsi Bengkulu mencapai 4.266,2 ha (BPS 2004).

Terdapat indikasi konversi sawah tersebut berkaitan dengan pengembangan subsektor perkebunan di Propinsi Bengkulu sejak akhir 1980-an. Data Dirjen Perkebunan pada tahun 2000 menunjukkan luas areal perkebunan kelapa sawit (Elaeis guineensis Jacq) di Propinsi Bengkulu adalah 64.613 ha (Dirjen Perkebunan 2001). Tampaknya keberadaan perusahaan perkebunan di 
Bengkulu, baik secara langsung maupun tidak, memberikan dampak terhadap sistem pertanian sawah di desa sekitar. Dari 64.613 ha lahan perkebunan kelapa sawit di Bengkulu, sekitar 55\% (35.739 ha) merupakan lahan perkebunan besar swasta. Dominannya pengembangan kelapa sawit berbasis perusahaan, mendorong meningkatnya permintaan bahan baku pabrik kelapa sawit dari perkebunan rakyat.

Secara sosiologis, gejala konversi lahan bukan semata-mata fenomena pengalihan fungsi agroekosistem melainkan peristiwa ini boleh jadi akan diikuti oleh penyusunan pola hubungan sosial yang baru. Kelapa sawit sebagai komoditas tanaman komersial (cash crops) bagi petani merupakan sumber penerimaan uang tunai rumah tangganya. Dengan kata lain, tanda-tanda bertani untuk mengejar keuntungan semakin jelas. Disamping itu, karakteristik produksi kebun kelapa sawit sebagai tanaman tahunan (perennial crops) menuntut pola hubungan kerja yang sesuai dengan perkembangan umur tanaman. Bagaimana proses konversi lahan itu terjadi? Bagaimana pula struktur produksi kebun petani?

Menurut Kartodirdjo dan Suryo (1991), sejarah perkebunan merupakan internalisasi pertanian komersial yang sangat erat kaitannya dengan ekspansi kolonialisme, kapitalisme, dan modernisasi. Adopsi sistem perkebunan dapat merubah tatanan sosial dalam konteks produksi kebun untuk pasar. Tetiani (2005) menemukan gejala mobilitas sosial pada perkebunan teh di Jawa Barat yang menandai dualisme ekonomi (Boeke dalam Mackie 1980) memudar melalui proses modernisasi perkebunan. Gejala perubahan ini merupakan implikasi tindakan rasional petani dalam mengalokasikan sumberdaya yang tersedia. Di dalam perspektif teori pilihan rasional (Hechter dalam Turner 1989; Popkin 1986), tindakan aktor berpijak pada pilihan individu dan orientasi tujuan untuk memaksimalkan keuntungan. Dalam kerangka tindakan rasional petani mengadopsi sistem perkebunan terbentuklah hubungan timbal balik antar berbagai aktor dalam konteks yang lebih luas, yaitu industri kelapa sawit. 
Kerangka berpikir di atas membingkai penelitian ini untuk mengkaji proses konversi sawah menjadi kebun kelapa sawit, profil kebun petani, dan mengkonsepsi struktur produksi kebun di tingkat desa.

\section{METODE PENELITIAN}

Penelitian ini dilaksanakan di Desa Pasar Seluma Kecamatan Seluma Selatan (etnis Serawai) dan Desa Rawasari Kecamatan Seluma Timur (etnis Jawa eks transmigran) Kabupaten Seluma Propinsi Bengkulu pada bulan Juni-Agustus 2007. Pengambilan data kuantitatif dilakukan melalui survei rumah tangga dan data kualitatif melalui wawancara mendalam. Selain itu juga dilakukan pengambilan data sekunder. Responden ditentukan sebanyak 30 orang kepala rumah tangga petani kelapa sawit di setiap desa dengan teknik acak sederhana sedangkan informan ditentukan sebanyak 13 orang dengan teknik bola salju. Data-data kuantitatif dianalisis dengan teknik deskriptif. Data-data kualitatif dianalisis dengan teknik analisis domain. Untuk setiap analisis tersebut, digunakan teknik pembandingan antara kedua desa penelitian.

\section{HASIL DAN PEMBAHASAN}

\section{Proses Konversi Lahan Sawah Menjadi Kebun Kelapa Sawit}

Keputusan menanam kelapa sawit yang ditempuh dengan jalan mengkonversi sawah merupakan suatu keputusan revolusioner pada diri petani karena kelapa sawit adalah jenis tanaman baru bagi petani. Terjadinya konversi sawah merupakan hasil interaksi aktor petani dengan buruh perusahaan perkebunan swasta, migran etnis Batak, dan Dinas Perkebunan yang terjadi dalam konteks perekonomian desa yang sedang merosot. Masyarakat Desa Pasar Seluma mengalami kekurangan akses terhadap sumberdaya hutan, kebun campuran, dan sawah akibat penempatan transmigrasi dan pencadangan lahan untuk perkebunan kelapa sawit salah satu perusahaan perkebunan swasta. Masyarakat desa Rawasari berada dalam masa transisi pengalihan dari pembinaan transmigrasi ke Pemerintah Daerah Bengkulu Selatan. Bantuan 
pangan sudah tidak ada sementara produksi sawah mulai menurun akibat sebagian besar lahan bergambut dan infrastruktur irigasi belum siap. Menilik konteks ini maka konversi dilakukan dengan motif memecahkan permasalahan ekonomi rumah tangga petani.

Proses konversi sawah terjadi dalam tiga tahap (Tabel 1). Pertama, periode 1990-1993 yakni pencarian alternatif solusi atas masalah keterbatasan faktor edafik (tanah bergambut dan pasang surut) bagi produksi sawah. areal sawah Desa Pasar Seluma sebagian besar terkena pengaruh pasang naik dan pasang surut air laut dan kondisi tanah bergambut sekitar satu meter. Kondisi faktor edafik (tanah) tersebut menyulitkan petani untuk memproduksi sawah dengan sistem tiga kali panen setahun. Bahkan ketebalan gambut di areal sawah Desa Rawasari mencapai dua meter. Sebaliknya produksi kebun kelapa sawit tidak menyulitkan petani karena tanaman kelapa sawit dapat tumbuh secara baik di berbagai jenis tanah seperti podsolik, latosol, hidromorfik kelabu, aluvial, atau regosol (Fauzi et al 2003) dengan ketebalan gambut dapat ditoleransi mencapai $150 \mathrm{~cm}$ (Pahan 2007). Dengan keadaan demikian, tanaman kelapa sawit relatif mudah tumbuh dan dapat beradaptasi dengan sifat kimia tanah yang ekstrem sekalipun, dengan catatan ketinggian lahan tidak lebih dari 500 meter di atas permukaan laut (Fauzi et al 2003). Dengan demikian pemilihan alternatif untuk mengkonversi sawah merupakan pilihan logis sebagai langkah mengatasi inefisiensi teknis produksi sawah.

Berikutnya periode 1993-1998 adalah penumbuhan kesadaran dan upaya meniru yang merupakan hasil pengamatan serta pertukaran pengalaman dengan para buruh salah satu perusahaan perkebunan swasta dan migran etnis Batak. Kebutuhan mendesak bagi petani yang direpresentasikan melalui bertahannya usaha-usaha subsisten bertemu dengan tersedianya alternatif jalan keluar yang didemonstrasikan oleh migran Batak dan perusahaan perkebunan swasta. Pada mulanya aktivitas perusahaan perkebunan swasta pada tahun 1990 tidak serta merta menginisiasi petani untuk meniru karena tidak direkrutnya penduduk sebagai tenaga kerja 
perkebunan. Meskipun setiap hari mereka menyaksikan para buruh bekerja di kebun, fakta ini hanya membangunkan sedikit kesadaran bahwa ada komoditas tanaman tahunan yang sedang diusahakan dalam skala besar, namun belum menggugah keinginan untuk mencoba meniru.

Kehadiran migran etnis Batak di Pasar Seluma pada tahun 1993 membeli lahan-lahan penduduk untuk ditanami kelapa sawit memicu atensi dan apresiasi petani untuk mencoba menanam kelapa sawit. Atensi dan apresiasi masyarakat kedua desa semakin meningkat ketika kebun perusahaan perkebunan swasta mulai menghasilkan pada tahun 1994. Pada tahun 1995 di Pasar Seluma ada dua petani yang menanam kelapa sawit di atas lahan 4 hektar. Karena tidak adanya pengetahuan yang memadai tentang budidaya kelapa sawit, usaha mereka menemui kegagalan. Perlahan-lahan mereka mendapatkan pengalaman dari hubungan sehari-hari dengan para migran dan perbincangan mengenai kelapa sawit semakin meluas. Jadi pada masa itu, imitasi petani serta sosialisasi aktor perusahaan perkebunan swasta dan migran Batak mulai mengisi ruang pengetahuan petani yang masih kosong.

Terakhir, adalah periode 1998-sekarang, yaitu pemilihan alternatif dan penerapan solusi. Pilihan untuk menanam kelapa sawit secara meluas terjadi setelah petani merasa memiliki pengetahuan yang cukup, ketersediaan modal, dan jaminan pembelian oleh pabrik kelapa sawit. Hal itu mereka tunjukkan dengan kesediaannya mengikuti program kemitraan petani, Bank Pembangunan Daerah Bengkulu Selatan (sekarang menjadi Bank Bengkulu Selatan), dan PTPN VII. Pengadaan modal usaha petani diusulkan melalui Kredit Koperasi Primer untuk Anggota (KKPA). Hasil panen kebun kelapa sawit petani akan dibeli oleh PTPN VII. Petani terhimpun dalam Koperasi Unit Desa (KUD) dengan kredit setiap petani sebesar 5,5 juta rupiah dalam bentuk bibit, pupuk, dan pestisida. KKPA Desa Rawasari dimulai pada tahun 1998 sedangkan Pasar Seluma baru pada tahun 1999. Maka pada tahun itu secara serentak petani menanam kelapa sawit di atas areal yang dulunya sawah. 
Tabel 1. Ringkasan Proses Konversi Sawah menjadi Kebun Kelapa Sawit

\begin{tabular}{|c|c|c|c|}
\hline Konteks Masalah & Tahapan & Wujud Tindakan & Keterangan \\
\hline $\begin{array}{l}\text { Perekonomian desa } \\
\text { merosot } \\
\text { Pasar Seluma: } \\
\text { Penurunan akses thd } \\
\text { sumberdaya hutan, }\end{array}$ & $\begin{array}{l}\text { Pencarian } \\
\text { alternatif solusi } \\
(1990-1993)\end{array}$ & $\begin{array}{l}\text { Pengamatan } \\
\text { perkebunan swasta } \\
\text { dan perbincangan } \\
\text { hangat mengenai } \\
\text { kelapa sawit. }\end{array}$ & $\begin{array}{l}\text { Faktor edafik menyebabkan } \\
\text { inefisiensi teknis produksi sawah: } \\
\text { keasaman tanah, pengeringan, \& } \\
\text { irigasi. }\end{array}$ \\
\hline $\begin{array}{l}\text { kebun campuran, \& } \\
\text { sawah akibat } \\
\text { penempatan } \\
\text { transmigrasi dan } \\
\text { pembukaan perkebunan } \\
\text { swasta } \\
\text { Rawasari: } \\
\text { Masa transisi UPT ke }\end{array}$ & $\begin{array}{l}\text { Penumbuhan } \\
\text { kesadaran dan } \\
\text { upaya meniru } \\
(1993-1998)\end{array}$ & $\begin{array}{l}\text { Sosialisasi buruh } \\
\text { perkebunan swasta } \\
\text { dan migran etnis } \\
\text { Batak serta imitasi } \\
\text { petani. Petani } \\
\text { mencoba menanam } \\
\text { kelapa sawit. }\end{array}$ & $\begin{array}{l}\text { Perkebunan swasta } \\
\text { membangunkan kesadaran } \\
\text { adanya alternatif solusi. Migran } \\
\text { Batak meningkatkan atensi dan } \\
\text { apresiasi terhadap kelapa sawit }\end{array}$ \\
\hline $\begin{array}{l}\text { desa yaitu pemdes } \\
\text { belum terbentuk, } \\
\text { bantuan pangan berakhir } \\
\text { tetapi produksi sawah } \\
\text { mulai menurun }\end{array}$ & $\begin{array}{l}\text { Pemilihan } \\
\text { alternatif dan } \\
\text { penerapan } \\
\text { solusi } \\
\text { (1998-skrg) }\end{array}$ & $\begin{array}{l}\text { Kesediaan petani } \\
\text { mengikuti tawaran } \\
\text { program } \\
\text { pengembangan } \\
\text { perkebunan rakyat: } \\
\text { melalui KKPA }\end{array}$ & $\begin{array}{l}\text { Model kemitraan petani, Bank BS, } \\
\text { PTPN VII menjawab keraguan } \\
\text { petani dalam hal modal dan } \\
\text { pasar. }\end{array}$ \\
\hline
\end{tabular}

\section{Profil Perkebunan Kelapa Sawit Petani}

\section{Lahan dan Produksi}

Kebun kelapa sawit petani di Pasar Seluma rata-rata 1,17 ha dan di Rawasari 2,85 ha. Sedikitnya lahan kebun di Pasar Seluma terkait dengan pembebasan tanah untuk pembangunan perkebunan swasta. Menurut Tim Inventarisasi Tanah BPN Propinsi Bengkulu, lahan garapan petani Pasar Seluma yang dicadangkan untuk perkebunan swasta tersebut seluas 851,75 ha (BPN Propinsi Bengkulu 1989). Jumlah petani yang menggarap tanah sebanyak 105 orang dengan rata-rata menguasai lahan 8,11 ha. Jadi selama proses itu, penduduk Pasar Seluma kehilangan lahan pertanian rata-rata 8,11 ha. Sedangkan di Rawasari, banyaknya kebun kelapa sawit petani diakibatkan proses pembelian lahan baik pada masa sebelum kelapa sawit maupun saat sudah menanam kelapa sawit. Petani Rawasari membeli tanah suku Serawai Desa Tanjungan dan Padang Genting yang umumnya masih berupa hutan atau semak-semak, bahkan sampai ada yang memiliki 12 ha dari hasil membeli. Total lahan desa-desa sekitar yang sudah dimiliki petani Rawasari kira-kira 200 ha. 
Pada dasarnya kebun kelapa sawit di Pasar Seluma adalah bekas tanah-tanah adat marga Seluma yang sudah dibagikan kepada setiap keluarga sedangkan di Rawasari adalah tanah-tanah pemberian negara pada masa transmigrasi tahun 1990 (lahan I dan II). Terdapat gejala akumulasi lahan kebun melalui pembelian tanah. Di Pasar Seluma persentase petani yang memperoleh lahan untuk kebun melalui pembelian lebih kecil $(26,67 \%)$ dibandingkan di Rawasari $(73,33 \%)$. Semua kebun menurut sumber lahan ini menjadi hak milik, tidak dijumpai kelembagaan penyakapan tanah (land tenancy) sebagaimana umum terjadi di desa-desa sawah (Wiradi 1978).

Perbedaan luas lahan ini berimplikasi pada tingkat produksi kelapa sawit yang berbeda pula. Luas kebun menghasilkan Pasar Seluma rata-rata 0,94 ha dan Rawasari 1,40 ha, umur tanaman berkisar antara 9-10 tahun dan rotasi panen 20-21 hari sekali, mengakibatkan produktivitas kebun kedua desa itu berbeda. Produksi kebun kelapa sawit Pasar Seluma sebesar $1.142,60 \mathrm{~kg} / \mathrm{ha} / \mathrm{panen}$ (19.859 ton/ha/tahun) sedangkan Rawasari mencapai 1.334,52 kg/ha/panen $(23,195$ ton/ha/tahun). Perbedaan ini terjadi karena petani Rawasari dengan kebun menghasilkan di atas 2 ha sudah menerapkan rotasi panen 2 minggu sekali.

Memang benar produktivitas turut ditentukan oleh kualitas bibit kelapa sawit yang ditanam. Di bawah program KKPA yang difasilitasi pemerintah, petani menerima bibit dalam jenis yang bermacam-macam. Ada dura dan tenera. Pembagian bibit tidak dilakukan dengan cara membedakan jenis bibit tersebut akibatnya dalam kebun petani umumnya terdapat kedua jenis bibit kelapa sawit itu. Persentase petani Pasar Seluma yang menanam kedua jenis bibit tersebut mencapai $56,67 \%$ dan Rawasari 33,33\%. Fakta ini mengungkapkan bahwa bibit bukan faktor yang menyebabkan perbedaan produktivitas karena kedua jenis bibit ini sama-sama baiknya (Fauzi et al 2003).

Sungguhpun produktivitas kebun petani di kedua desa ini masih di bawah standar PPKS Medan, yaitu golongan kelas lahan III produktivitas ditetapkan 25 ton/ha/tahun periode umur 
tanaman 8-13 tahun (Fauzi et al 2003), sistem rotasi panen di atas 2 minggu sekali ini adalah titik rasional bagi petani. Dengan tingkat harga seribu rupiah, sistem tiga mingguan dinilai paling efisien. Memperpendek jangka panen (dua mingguan) dipastikan tidak menguntungkan karena produksi tandan kelapa sawit lebih sedikit sedangkan upah kerja panen tetap. Disamping itu pemendekan jangka panen akan mengurangi jumlah buah yang siap panen untuk periode panen berikutnya. Jadi produktivitas tersebut juga menjadi batas rasional tindakan petani saat ini.

\section{Pola Hubungan Kerja}

Jenis kerja produksi kebun petani mencakup menebas, melingkari, menyemprot, memupuk, melepah dan memanen. Terdapat perbedaan pola penggunaan tenaga kerja di kedua desa penelitian untuk semua jenis kerja tersebut (Tabel 2).

Tabel 2. Perbedaan Pola Penggunaan Tenaga Kerja Perkebunan Kelapa Sawit

\begin{tabular}{lll}
\multicolumn{1}{c}{ Uraian } & \multicolumn{1}{c}{ Pasar Seluma } & \multicolumn{1}{c}{ Rawasari } \\
\hline a. Sumber Tenaga Kerja & Dalam rumah tangga & Luar rumah tangga \\
b. Status Tenaga Kerja Luar & Kerabat & Bukan kerabat \\
c. Sistem Kerja & Kerja Borongan & Kerja Harian \\
d. Besarnya Upah & $40.000-60.000$ per ton atau ha & $30.000-50.000$ per hari \\
\hline
\end{tabular}

Dalam tulisan ini cukup disajikan perbedaan pola penggunaan tenaga kerja memanen kelapa sawit. Berdasarkan Gambar 1, persentase petani Pasar Seluma lebih dominan menggunakan tenaga kerja dari dalam rumah tangga (60\%) sedangkan petani Rawasari lebih dominan menggunakan tenaga kerja dari luar rumah tangga (70\%). Berdasarkan Gambar 2, semua (100\%) petani Pasar Seluma yang menggunakan tenaga kerja luar, merekrut orang yang masih kerabat sebagai tenaga kerjanya sedangkan petani Rawasari lebih dominan merekrut orang yang bukan kerabat. Berdasarkan Gambar 3, semua (100\%) petani Pasar Seluma memanen dengan sistem kerja borongan sedangkan petani Rawasari cenderung memilih sistem kerja harian. Meskipun sistem kerja yang digunakan berbeda, kewajiban pemilik kebun selain membayar upah juga menyediakan makan siang bagi para pekerjanya. Perbedaan lainnya terletak pada besarnya upah yang dibayarkan pada sistem kerja borongan di Pasar Seluma yang lebih tinggi 
dibandingkan sistem kerja harian di Rawasari (Tabel 2). Meskipun kerja harian, semua petani di Rawasari memanen kelapa sawit selesai dalam waktu satu hari.

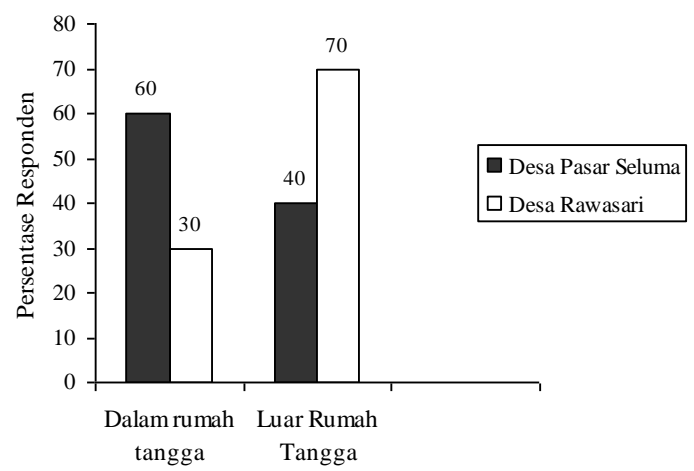

Gambar 1. Penggunaan tenaga kerja memanen menurut sumber tenaga kerja

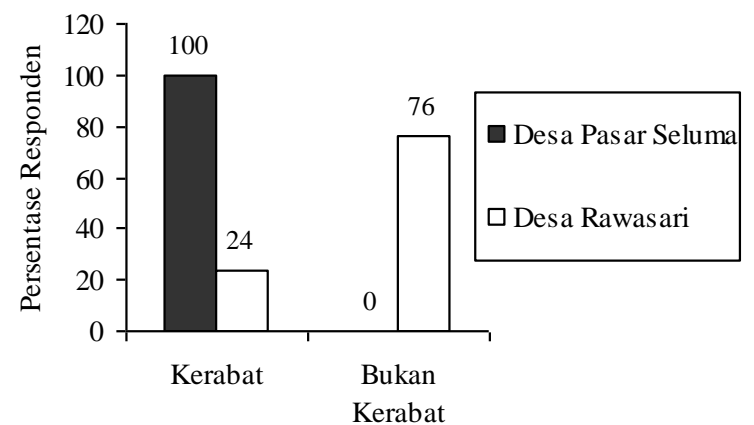

Gambar 2. Penggunaan tenaga kerja memanen menurut status tenaga kerja luar

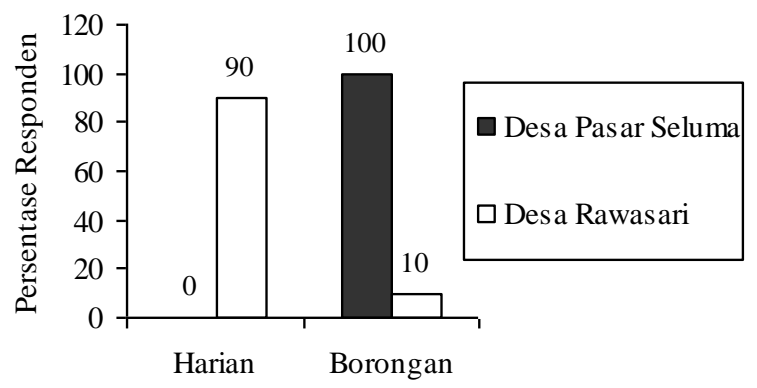

Gambar 3. Sistem kerja memanen yang digunakan petani

\section{Organisasi Penjualan}

Organisasi penjualan merupakan rantai penghubung antara petani dengan pabrik kelapa sawit karena adanya tuntutan jaminan pembelian bagi petani dan jaminan kesinambungan produksi bagi pabrik. Organisasi penjualan memastikan kapan kelapa sawit akan dipanen, berapa harga yang diterima petani dan kapan pembayarannya, serta jaminan seberapapun hasil panen 
akan dibeli oleh pedagang atau toke. Jadi organisasi penjualan melibatkan petani, pedagang atau toke, dan pabrik kelapa sawit. Munculnya organisasi penjualan dilatarbelakangi tidak dicapainya MoU antara pemerintah dengan PTPN VII dalam pembelian kelapa sawit petani KKPA sampai dengan kebun berproduksi.

Mekanisme penjualan kelapa sawit ke pabrik diatur melalui jaringan para pedagang yang memegang DO (demand order) dari pabrik tertentu. Pabrik mengharuskan pedagang besar yang akan menjual kelapa sawit menunjukkan dokumen DO sebelum memasuki pintu penimbangan. DO itu sendiri merupakan dokumen yang menunjukkan bahwa pedagang tertentu terdaftar secara resmi pada pabrik tertentu sebagai pemasok. Jadi tanpa DO kelapa sawit tidak dapat dijual.

Di desa penelitian terdapat dua organisasi penjualan, yaitu organisasi penjualan dengan pemegang DO DM dan MW yang berkedudukan di Tais. Organisasi MW memiliki pedagang besar sebanyak 4 orang di Pasar Seluma dan 2 orang di Rawasari, 2 orang pedagang kecil dan 3 koordinator petani di Rawasari. Organisasi DM memiliki 3 orang pedagang besar di Rawasari. Hubungan antara petani, pedagang, pemegang DO, dan pabrik pada dua organisasi penjualan ini digambarkan sebagai berikut (Gambar 4).

Pola penjualan di tingkat petani pada dasarnya ada dua, yaitu menggunakan koordinator (Rawasari) dan tanpa koordinator (kedua desa). Petani tanpa koordinator dapat menjual kepada pedagang kecil atau langsung kepada pedagang besar (kedua desa). Pola pengorganisasian semacam ini mendudukkan petani sebagai produsen penerima harga (price taker) karena harga ditetapkan pabrik dan keharusan pedagang menggunakan DO tertentu ketika menjual ke pabrik. Harga pabrik pada minggu tertentu ditetapkan Rp 1.270 diterima petani antara Rp 890-Rp 1.050. Tingkat keuntungan kotor yang diterapkan oleh pedagang besar berkisar antara Rp 40-Rp 50 per $\mathrm{kg}$ tandan kelapa sawit. Sedangkan pedagang kecil mengambil keuntungan sebesar Rp 25-Rp 30 per kg tandan kelapa sawit. Jika hanya memperhatikan tingkat keuntungan yang diinginkan toke 
sawit dan pemegang DO, maka harga pabrik Rp 1.270 diterima petani berkisar antara Rp 1.166,9 s.d Rp 1.151,9. Jika menjual langsung ke pedagang besar berkisar antara Rp 1.181,9 s.d Rp 1.191,9. Harga ini berlaku selama satu minggu dari hari jumat hingga rabu minggu berikutnya.

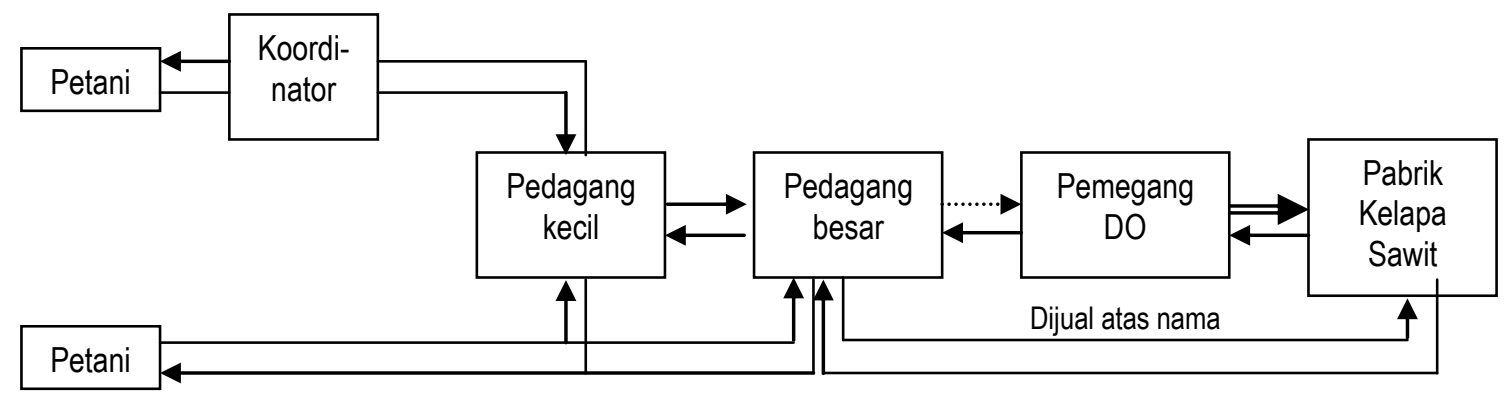

Gambar 4. Organisasi Penjualan Kelapa Sawit

Keterangan:

- Pengumpulan kelapa sawit

$\longrightarrow$ Penjualan kelapa sawit

$\longleftarrow$ Pembentukan harga

$\rightarrow$ Kontrak penggunaan DO

$\Longrightarrow$ Kontrak pemasokan kelapa sawit

Semakin berkurangnya harga petani ini dipengaruhi juga oleh faktor lokasi tumpukan buah kelapa sawit. Semakin susah diakses oleh kendaraan pengangkut maka semakin tinggi harganya. Sedangkan kualitas buah tidak terlalu berpengaruh karena untuk di desa pedagang memukul rata jenis dan kualitas buah kelapa sawit pada semua petani. Satu-satunya kriteria tandan itu normal atau tidak adalah timbangan tandan itu sendiri. Tandan dengan berat lebih dari 8 kilogram ditetapkan sebagai tandan normal. Tandan yang beratnya tidak mencapai 8 kilogram dianggap sebagai buah pasir. Untuk buah pasir selisih harganya mencapai Rp 100-Rp 200 per kilogram lebih rendah. Sedangkan buah yang memberondol dianggap sebagai tandan normal.

\section{Struktur Produksi Kebun}

Pada sistem pertanian sawah, produksi ditandai oleh hubungan penyakapan lahan (land tenancy). Penyakapan lahan terjadi akibat tingginya penawaran tenaga kerja di desa, sementara ketersediaan lahan semakin menipis (Hayami dan Kikuchi 1987). Dalam hal ini produksi lahan 
dibangun atas dasar hubungan antara pemilik tanah dengan penggarap di dalam kelembagaan penyakapan lahan baik itu sewa, bagi hasil, maupun gadai (Wiradi 1978). Jadi produksi sawah dapat berlangsung tanpa adanya kepemilikan lahan secara mutlak (hak milik).

Disamping itu pola produksi dalam sistem pertanian sawah ditandai juga oleh hubungan kerja yang mendasarkan pada prinsip pemerataan hasil. Prinsip pemerataan ini berlangsung dalam pola hubungan pemanenan seperti bawon, kedokan, dan tebasan (Wiradi 1978). Dalam pola pemanenan ini, penduduk desa memiliki semacam hak untuk memanen sebidang sawah tertentu milik petani lain, baik petani pemilik lahan maupun petani penggarap.

Memang benar kecenderungan pola pemerataan itu memudar menurut Hayami dan Kikuchi (1987), yakni bawon dan kedokan mulai dilaksanakan lebih terbuka dalam perekrutan tenaga pemanen. Demikian pula mekanisasi pertanian mendorong berkembangnya sistem tebasan yang dianggap lebih praktis bagi petani. Hanya saja pemanenan secara bersama-sama tetap dipraktikkan petani. Bentuk yang mengalami perubahan hanya pola pembagian hasilnya, yaitu semakin membesarnya perbandingan bagian panen antara pekerja dengan petani (Hayami dan Kikuchi 1987). Tebasan juga tidak dipraktikkan dalam prinsip cash and carry, akan tetapi calon penebas sudah memesan terlebih dahulu sebelum dilakukan pemanenan. Jadi pembayaran dilakukan sesudah memanen (Wiradi 1978).

Kedua ciri tersebut, yaitu pola penyakapan lahan dan prinsip pemerataan dalam hubungan kerja, tidak ditemui pada sistem produksi kebun kelapa sawit di lokasi penelitian. Semua kebun petani adalah menjadi hak milik yang diperoleh baik dari pembagian tanah adat, pembagian tanah transmigrasi, warisan, maupun membeli. Jadi tidak ada pola penggarapan kebun sebagaimana penggarapan sawah yang menganut sistem bagi hasil atau sewa. Petani pemilik kebun mengelola sendiri kebunnya baik dikelola dengan cara merekrut tenaga kerja dari dalam rumah tangga maupun luar rumah tangga. 
Hal ini pula yang melandasi pola hubungan kerja kebun kelapa sawit murni berbentuk hubungan pengupahan antara pemilik kebun dengan pekerja. Pemilik kebun mengupah tenaga kerja untuk jenis kerja produksi tertentu dimana antara keduanya terikat dalam satu aturan mengenai jenis dan bentuk kerja serta besarnya upah. Jadi kerja kebun tidak menganut prinsip pemerataan hasil. Penemuan ini juga berbeda dengan pola hubungan kerja pada kebun karet. Menurut Scholz dalam Planck (1990) pada produksi kebun karet juga dijumpai hubungan kerja bagi hasil. Dalam sistem ini pekerja menyadap areal kebun tertentu kemudian hasilnya dibagi dengan pemilik kebun sebesar 2:3.

Ditinjau dari dua segi, yaitu struktur agraria dan pola hubungan kerja, sistem produksi kebun kelapa sawit di lokasi penelitian tidak menunjukkan struktur agraris sebagaimana sistem produksi sawah. Dalam struktur agraris, tanah cenderung lebih mudah dikuasakan kepada penggarap untuk berproduksi serta pengorganisasian kerja diatur oleh norma-norma tradisional yang melekat erat dalam struktur sosialnya. Dengan kata lain, pertanian agraris tumbuh dan berkembang mengikuti perkembangan kelembagaan yang hidup dalam masyarakat.

Ketika teknologi diintroduksi dalam rangka peningkatan produksi maka teknologi akan dimanipulasi oleh golongan-golongan sosial di desa untuk tetap melindungi tradisi kerja pertaniannya. Geertz (1983) mengemukakan ketika teknologi masuk maka produksi memang meningkat per satuan lahan tetapi tidak merubah pola kerjasama yang sudah ada. Dengan kata lain peningkatan produksi tidak serta-merta meningkatkan produksi per unit tenaga kerja akibat semakin banyaknya penduduk yang ditampung di lahan pertanian. Masyarakat desa merespon perubahan demografi dan perkembangan teknologi secara involutif. Ekologi sawah digambarkan memiliki sifat kelenturan untuk menampung seluruh tenaga kerja yang semakin banyak pada lahan yang tetap. Dalam kondisi seperti inilah struktur agraris cenderung menganut prinsip pemerataan hasil, atau dalam istilah Geertz disebut dengan shared poverty. 
Bagaimana dengan struktur produksi kebun kelapa sawit petani? Kuhren dalam Planck (1990) berpendapat bahwa sistem perkebunan di negara berkembang cenderung dikelola dengan sistem kapitalistik. Perkebunan dikelola dalam skala besar dengan mengutamakan tanaman tahunan seperti teh, kopi, pisang, coklat, sisal, dan kelapa sawit. Tipe pertanian ini dikembangkan untuk memenuhi permintaan pasar luar negeri atau berorientasi ekspor. Pelaku perkebunan biasanya adalah perusahaan-perusahaan besar swasta.

Kebun kelapa sawit petani di lokasi penelitian memiliki keterbatasan dalam skala usaha. Jadi tidak dapat menyamai perkebunan yang dikembangkan oleh perusahaan-perusahaan. Tentu dalam aspek pengelolaan juga memiliki perbedaan. Hanya saja perbedaan ini lebih ditunjukkan pada perbedaan skala produksi. Bentuk-bentuk pengorganisasian kerja kebun petani merupakan upaya imitasi dari pengorganisasian kerja perkebunan besar. Seorang pemilik kebun akan berusaha untuk mendapatkan tenaga kerja tertentu dari orang-orang yang sama. Jadi ada petani lain yang dijadikan semacam tenaga kerja tetap untuk jenis kerja tertentu yang umumnya ialah pemanenan. Ketika akan memanen, pemilik kebun memberitahukan kepada pekerjanya tentang hari panen. Pada saat dilakukan pemanenan, biasanya pemilik kebun mengarahkan bagian mana dulu yang akan dipanen dan menunjukkan tempat pengumpulan buah. Pemilik kebun telah menetapkan upah kerja sebelumnya. Setelah pekerjaan diselesaikan, upah dibayarkan pada malam harinya.

Produksi kebun petani terhubungkan dengan pasar dunia melalui perusahaan besar kelapa sawit penghasil minyak kelapa sawit. Sebelum mencapai pabrik minyak kelapa sawit, produksi kebun petani melalui organisasi penjualan di tingkat desa dan daerah. Jadi dalam konteks ini, kebun kelapa sawit petani merupakan entitas produksi bahan baku produk-produk turunan olahan minyak kelapa sawit. Pada level ini, produksi kebun dikelola dengan mengerahkan tenaga kerja baik dalam rumah tangga maupun luar rumah tangga. 
Sebagai entitas produksi, perkembangan produksi kebun petani ditentukan pula oleh kekuatan modal petani. Petani dapat mengakses modal dari pedagang/toke sawit tempatnya menjual. Disamping berperan sebagai jaringan pemasaran, aktor pedagang kelapa sawit memainkan peran pula sebagai penyedia dana bagi petani-petani tertentu yang produktif. Bentuk permodalan ini berlangsung dalam transaksi pinjaman uang untuk kebutuhan membeli lahan, bibit, dan sarana produksi. Hasil wawancara terhadap petani yang pernah meminjam uang kepada toke sawit untuk membeli lahan 3 ha di Rawasari mengungkapkan bahwa "para toke sawit tidak segan-segan memberikan pinjaman baik untuk keperluan sehari-hari ataupun untuk meningkatkan hasil kebun petani." Menurutnya langkah itu ditempuh seorang toke sawit bukan semata-mata menolong petani yang membutuhkan dana melainkan toke sawit berkomitmen untuk peningkatan hasil panen yang mereka beli dari petani. Toke sawit semakin senang jika ada petani yang menambah pinjamannya.

Dalam konteks ini, transaksi pinjaman modal merupakan pertukaran (exchange) materi dan pembentukan nilai mutual. Aktor petani membutuhkan modal usaha yang cukup besar untuk peningkatan produksi dan perluasan kebun sementara para toke sawit berkepentingan meraup keuntungan dari pembelian kelapa sawit petani. Hubungan mutualistik antara pedagang selaku pemberi modal dan petani selaku pemilik kebun membentuk semacam struktur industri produksi kelapa sawit dalam rangka memenuhi permintaan bahan baku minyak kelapa sawit di regional Propinsi Bengkulu dan sekitarnya.

Dengan kondisi seperti ini, yakni sebagai entitas produksi yang digerakkan oleh modal dari pedagang, petani menjadi aktor pasif. Petani menduduki posisi sebagai penerima harga (price taker). Banyaknya pedagang yang beroperasi di desa memang menyediakan alternatif penjualan bagi petani. "Selisih harga sepuluh rupiah saja bisa menyebabkan petani berpindah pedagang", demikian pengakuan seorang toke kelapa sawit. Kesempatan berpindah-pindah 
pedagang ini tidak serta merta meningkatkan posisi petani dalam hubungan perdagangan buah kelapa sawit. Dengan struktur yang tidak berimbang, dimana arus harga datang dan ditentukan oleh pihak pabrik, harga mengalir melalui jaringan pedagang menuju petani. Petani tidak memiliki kuasa apa-apa terhadap harga yang ditimpakan terhadap hasil panennya.

Rasionalitas yang dijunjung petani adalah bagaimana menjual kelapa sawitnya mengingat hasil kebun ini tidak dapat dikonsumsi secara langsung. Kelapa sawit bukan komoditas subsisten. Para pedagang memahami betul karakteristik petani yang tidak mungkin tidak menjual kelapa sawit. Kepercayaan dibangun oleh pedagang antara lain dengan memberi pinjaman kepada para petani yang menjadi langganannya. Petani merasa lebih nyaman lagi karena pinjaman ini tidak bersyarat apapun. Disamping tanpa bunga, potongan hasil penjualan tidak selalu diterapkan pada saat petani menjual kelapa sawitnya. Bahkan petani juga tidak dilarang jika ingin menjual kelapa sawitnya kepada pedagang lain.

Keluar masuknya petani yang menjual tanpa koordinator dari satu pedagang ke pedagang lainnya, belum mendorong petani menempati posisi yang lebih setara dalam hubungan jual beli kelapa sawit. Mereka hanya mendapatkan kesempatan bebas menjual kepada pedagang yang bergerak langsung ke desa, tetapi belum mampu menembus jaringan itu ke pabrik kelapa sawit. Jadi jaringan perdagangan buah kelapa sawit yang mengharuskan penjualan dengan dokumen DO adalah struktur pasar yang membatasi penguatan kapasitas petani. Lagi pula selisih harga per kilogram antara satu pedagang dengan pedagang lain hanya berkisar 25-50 rupiah, dalam skala produksi yang terbatas tidak memberikan pengaruh penerimaan yang besar. Dengan demikian sebetulnya organisasi penjualan yang ada belum mendorong posisi petani berada pada struktur yang kuat akibat struktur organisasi penjualan yang monopolistik sehingga menimbulkan hubungan tidak adil dan cenderung belum memberdayakan petani.

KESIMPULAN DAN IMPLIKASI KEBIJAKAN 
Terbentuknya perkebunan kelapa sawit rakyat merupakan gejala sosiologis yang dapat ditinjau dari segi aktor petani mengkonversi lahan sawah. Kegiatan mengembangkan perkebunan kelapa sawit secara masif di desa-desa hingga tanaman menghasilkan, mendorong terbentuknya jaringan sosial perdagangan dalam struktur produksi industri kelapa sawit yang komersial. Menyangkut konversi lahan dan struktur ini dapat dikemukakan beberapa hal sebagai berikut.

1. Konversi sawah merupakan langkah rasional yang ditempuh petani untuk mengatasi persoalan ekonomi dengan memanfaatkan peluang lemahnya insentif kebijakan dan kontrol pemerintah di subsektor tanaman pangan. Apabila konversi sawah dapat mengancam stabilitas pangan, sosial, dan ekonomi maka sudah sewajarnya pemerintah menggiatkan kembali pembangunan di subsektor tanaman pangan.

2. Bentuk-bentuk penguasaan lahan, teknik produksi, dan hubungan kerja merupakan fungsi rasionalitas petani dalam mendatangkan keuntungan. Status sosial lama, yakni sebagai petani sawah atau nelayan masih mewarnai orientasi produksi petani kebun. Fenomena ini tidak dapat diabaikan sehingga pembatasan luas lahan minimal dalam berkebun menjadi penting agar perkebunan bukan hanya menjadi sektor penyelamat subsisten.

3. Petani hanya menguasai bagian on farm dengan produktivitas rendah sehingga posisinya dalam industri kelapa sawit masih termarginalkan. Di dalam konteks struktur produksi industri kelapa sawit, aktor petani berperan sebagai entitas produksi yang berposisi sebagai penerima harga. Tingkat produksi kebun petani itu sendiri juga ditentukan oleh kekuatan modal petani yang bersumber dari jaringan sosial para toke/pedagang. Bertolak dari hal ini, pemberdayaan petani kelapa sawit dapat dilakukan melalui kebijakan pemerintah dalam rangka mendekatkan produksi kebun petani dengan pabrik pengolahan kelapa sawit.

\section{DAFTAR PUSTAKA}

Ashari. 2003. Tinjauan tentang Alih Fungsi Lahan Sawah ke Non Sawah dan Dampaknya di Pulau Jawa. Forum Penelitian Agro Ekonomi Vol 21, No. 2, Desember. Hal. 83-98. 
[BPN Propinsi Bengkulu]. 1989. Inventarisasi Tanah dalam rangka Penyelesaian Hak Tanah pada Lokasi Perkebunan Kelapa Sawit atas nama PT AA di Kecamatan Perwakilan Sukaraja, Kecamatan Seluma, Kabupaten Bengkulu Selatan. (Laporan penelitian). Tanpa penerbit.

[BPS]. 2004. Statistik Potensi Desa Propinsi Bengkulu 2003. Katalog BPS 1610.17. Jakarta, BPS.

[Dirjen Perkebunan]. 2001. Statistik Perkebunan Indonesia 2000. Jakarta, Dirjen Perkebunan.

Fauzi Y, Widyastuti YE, Satyawibawa I, Hartono R. 2003. Kelapa Sawit: Budidaya, Pemanfaatan Hasil dan Limbah, Analisis Usaha dan Pemasaran. Edisi revisi. Jakarta, Penebar Swadaya.

Geertz C. 1983. Involusi Pertanian: Proses Perubahan Ekologi di Indonesia. (terj. cet. ke-2). Jakarta, Bhratara Karya Aksara.

Hayami, Y dan M. Kikuchi. 1987. Dilema Ekonomi Desa: Suatu Pendekatan Ekonomi terhadap Perubahan Kelembagaan di Asia. Jakarta, Yayasan Obor Indonesia.

Hechter M. 1989. Rational Choice Foundations of Social Order. Dalam Jonathan H. Turner (ed). Theory Building in Sociology: Assessing Theoritical Cumulation. Newbury Park, London, New Delhi, Sage Publications.

Kartodirdjo S dan Suryo. 1991. Sejarah Perkebunan di Indonesia: Kajian Sosial Ekonomi. Yogyakarta, Penerbit Aditya Media.

Kuhren F. 1990. Struktur Pertanian (terj). Dalam Ulrich Planck (ed). 1990. Sosiologi Pertanian (terj). Jeakarta, Yayasan Obor Indonesia.

Kustiwan I. 1997. Konversi Lahan Pertanian di Pantai Utara Jawa. Prisma No. 1 Tahun XXVI, Januari. Hal. 15-31.

Mackie JAC. 1980. The Concept of Dualism and Its Application to Indonesia Agriculture. Dalam RG Garnaut dan PT McCawley (eds). Indonesia: Dualism, Growth and Poverty. Canberra, Research School of Pacific Studies, ANU.

Popkin S. 1986. Petani Rasional (terj). Jakarta, Yayasan Padamu Negeri.

Pahan I. 2007. Panduan Lengkap Kelapa Sawit: Manajemen Agribisnis dari Hulu hingga Hilir. Jakarta, Penebar Swadaya.

Rajagukguk,E. 1995. Hukum Agraria, Pola Penguasaan Tanah dan Kebutuhan Hidup. Jakarta, Chandra Pratama.

Scholz U. 1990. Geografi Pertanian di Sumatera. Dalam Ulrich Planck (ed). Sosiologi Pertanian (terj). Jakarta, Yayasan Obor Indonesia.

Tetiani A. 2005. Memudarnya Dualisme Ekonomi: Studi Mobilitas Sosial Komunitas Perkebunan Teh Kertamanah, Pengalengan, Jawa Barat. Tesis. Bogor, Sekolah Pascasajana IPB.

Wiradi G. 1978. Rural Development and Rural Institutions: A Study of Institutional Changes in West Java. Rural Dynamic Series No. 6, Bogor, AES. 